\title{
Spatial congruence between biodiversity and ecosystem services in a forest landscape in southern Chile: basis for conservation planning
}

\author{
Congruencias espaciales entre biodiversidad y servicios ecosistémicos \\ en un paisaje forestal en el sur de Chile: bases para la planificación de la conservación
}

\author{
James Rodríguez-Echeverry a*, Cristian Echeverría ${ }^{\text {b }}$ \\ Carlos Oyarzún ${ }^{\text {, }}$ Luis Morales ${ }^{\text {d }}$

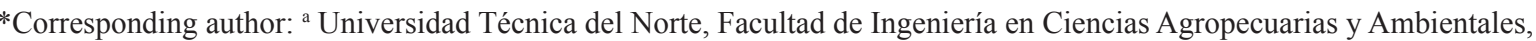 Ibarra, Ecuador, tel.: 59306 2997800,jjrodriguez@utn.edu.ec
${ }^{\mathrm{b}}$ Universidad de Concepción, Facultad de Ciencias Forestales, Concepción, Chile.
c Universidad Austral de Chile, Facultad de Ciencias, Valdivia, Chile.
${ }^{d}$ Universidad de Chile, Facultad de Ciencias Agronómicas, Santiago de Chile, Chile.

\begin{abstract}
SUMMARY
There is a need for a better understanding on how biodiversity and ecosystem services are spatially related and assess to what extent the conservation of biodiversity will ensure the provision of services. In the Río Cruces watershed (Chile) the spatial congruence between biodiversity and water supply, erosion control and soil accumulation services was assessed using spatially explicit models, geographically weighted regression and overlap analyses. Biodiversity registered a positive spatial relationship with the three ecosystem services. The local $\mathrm{R}^{2}$ value explained up to $95 \%, 68 \%$ and $37 \%$ of the variance for soil accumulation, water supply and erosion control, respectively. High spatial congruence ( $>67 \%)$ was registered between biodiversity and ecosystem services hotspots. Our study recommends that decision makers develop plans and share efforts for conservation of biodiversity and ecosystem services in 43 subwatersheds, which are $16.4 \%$ of the subwatersheds studied. We suggest that these efforts must be an integral part of environmental policies that need to be generated by the Chilean government.
\end{abstract}

Key words: anthropogenic landscapes, changing landscapes, human well-being, natural capital, spatially explicit models.

\section{RESUMEN}

Existe la necesidad de generar una mejor comprensión sobre cómo la biodiversidad y los servicios ecosistémicos se relacionan espacialmente y evaluar en qué medida la conservación de la biodiversidad asegura la provisión de servicios ecosistémicos. En la cuenca del río Cruces, en el sur de Chile, la congruencia espacial entre biodiversidad y los servicios ecosistémicos provisión de agua, control de erosión y acumulación de suelo fue evaluada usando modelos espacialmente explícitos, regresiones geográficamente ponderadas y análisis de superposiciones. La biodiversidad registró una positiva relación especial con los tres servicios ecosistémicos. El valor de $\mathrm{R}^{2}$ local explicó hasta un $95 \%$, $68 \%$ y $37 \%$ de la varianza para los servicios acumulación de suelo, provisión de agua y control de erosión, respectivamente. Alta congruencia especial (> $67 \%$ ) se registró entre biodiversidad y los hotspots de los tres servicios ecosistémicos. Este estudio recomienda a los tomadores de decisiones desarrollar planes y esfuerzos compartidos de conservación para la biodiversidad y los servicios ecosistémicos en 43 subcuencas, las cuales comprenden el 16,4 \% de las subcuencas estudiadas. Además, es necesario que los esfuerzos compartidos de conservación sean parte integral de políticas ambientales, las cuales deben ser generadas por el gobierno de Chile.

Palabras clave: paisajes antrópicos, paisajes cambiantes, bienestar humano, capital natural, modelos espacialmente explícitos.

\section{INTRODUCTION}

Biodiversity, broadly defined as the richness and abundance of genes, species and ecosystems (Díaz et al. 2006), is intrinsically related to ecosystem services, which are the benefits provided by ecosystems that contribute to making human life both possible and worth living (MA 2005). Biodiversity underpins most ecosystems and their services, which has justified the efforts of biodiversity conservation because of its importance in sustaining human livelihoods (Díaz et al. 2006). The degradation and unsustainable use of biodiversity and ecosystem services around the world now threatens the health and livelihood of many people (MA 2005). Accordingly, there is an urgent need to conserve these two resources (Turner et al. 2007). In the last decade, the protection of ecosystem services has been used 
to justify the efforts of biodiversity conservation (Turner et al. 2007). The adoption of this perspective may contribute to the optimization of conservation strategies (MA 2005). However, several authors have highlighted the need for a better understanding of how ecosystem services are spatially related to biodiversity (Turner et al. 2007, Onaindia et al. 2013) and to what extent biodiversity conservation will ensure the provision of multiple services (MA 2005, Díaz et al. 2006).

One of the challenges for conservation scientists and decision makers is to get a better understanding of the spatial relationships between biodiversity and ecosystem services (Vihervaara et al. 2010), as the spatial congruence between these two resources may allow simultaneous conservation efforts (de Groot et al. 2010). These relationships have not been extensively studied (Bai et al. 2011, Onaindia et al. 2013). Some studies have registered a high correlation and spatial congruence between biodiversity and ecosystem services (Chan et al. 2006, Egoh et al. 2009). Other studies have reported a moderate correlation and spatial congruence between them (Turner et al. 2007, Bai et al. 2011), whereas others have registered low correlations and spatial congruence between priority areas for biodiversity conservation and different ecosystem services (Chan et al. 2011, Onaindia et al. 2013). The ambiguity of these findings suggests there is a need to extend investigation into new regions that have not been extensively researched (Egoh et al. 2009), as this would provide a better understanding of the spatial relationship between biodiversity and ecosystem services (Onaindia et al. 2013) and an opportunity for efficient conservation planning by government decision makers (Turner et al. 2007).

Land-use change and land-use intensification (e.g., agricultural and commercial plantations) have been identified as the main global change drivers worldwide (MA 2005). Land-use change and land-use intensification can generate impacts on biodiversity (Myers et al. 2000). In this sense, the highest impacts on biodiversity have occurred at the habitat level, such as reduction and loss of habitat (Díaz et al. 2006), generating important changes in the provision of ecosystem services in different regions of the world (MA 2005). The impacts on biodiversity and ecosystem services have occurred due to the increase of human population (Vihervaara et al. 2010), which has entirely transformed natural landscapes into anthropogenic landscapes in the last decades (Bai et al. 2011). The need to conserve biodiversity and ecosystem services within anthropogenic landscapes has been recognized by practitioners (Vihervaara et al. 2010); this conservation would help to ensure the maintenance of multiple benefits for human populations that inhabit them (Vihervaara et al. 2010). Therefore, studying the spatial relationship between biodiversity at the habitat level and the provision of ecosystem services in anthropogenic landscapes will contribute to the development of alternatives for conservation planning and policy and decision-making (Turner et al. 2007).
The forest landscape of southern Chile, which includes Valdivian Temperate Forest, has been identified as a high priority area for biodiversity conservation in the world (Myers et al. 2000). This landscape supports the provision of key ecosystem services, such as water supply, which is essential not only for human life but also for agricultural and aquaculture activities (Oyarzún et al. 2011); and erosion control and soil accumulation services, which are important for soil productivity and conservation of the ecosystem integrity (de Groot et al. 2010). The forest landscape of southern Chile has undergone a progressive anthropization in recent decades due to intense and progressive land-use change and land-use intensification, such as pasture expansion for cattle grazing and commercial plantations (Echeverría et al. 2006). These land-use changes have generated important impacts on biodiversity, such as changes in plant species composition (RodríguezEcheverry et al. 2015), and the provision of water supply and erosion control services in different watersheds (Oyarzún et al. 2011).

The Río Cruces watershed in southern Chile is a landscape that has registered an increasing conversion of native forest habitat to commercial plantations in the last four decades (CONAF 2006). In recent years, it has been reported that various impacts derived from the forest industry have led to significant loss of wildlife (Di Marzio and McInnes 2005) and significant increase in the export of sediment in different affluents of the watershed (Oyarzún et al. 2011). The foregoing impacts have been the focus of discussion among government environmental organizations, forestry companies and the general public, which have highlighted the need to implement effective conservation strategies for biodiversity and ecosystem services (Di Marzio and McInnes 2005). In this context, studying the spatial relationship between biodiversity and ecosystem services would provide relevant information for the understanding of the relationship, resulting in better planning for conservation of these resources.

We assessed the spatial relationship between biodiversity and the provision of the following ecosystem services: water supply, erosion control and soil accumulation in the Río Cruces watershed in southern Chile. These services were selected due to their importance in the study landscape (Oyarzún et al. 2011) and their relevance to conservation planning (CONAF 2006). This study is based on a systematic methodology that identifies areas where biodiversity and ecosystem services should be protected. The study aims at answering the following questions: (i) how much of each service is generated in the landscape?, (ii) to what extent does biodiversity correlate with each service across the landscape? and (iii) to what extent does biodiversity overlap with ecosystem services? We hypothesize that the biodiversity and ecosystem services are spatially related, and in consequence the conservation of biodiversity ensures the provision of multiple services. 


\section{METHODS}

Study area. The Río Cruces watershed is located in Los Ríos Region, in southern Chile (figure 1). It is located between the cordilleras of the Andes and the coast $\left(39^{\circ} 17^{\prime} \mathrm{S}\right.$ and $39^{\circ} 50^{\prime} \mathrm{S}$ ) north of the city of Valdivia. The watershed $\left(3,640 \mathrm{~km}^{2}\right)$, characterized by a temperate climate, has a maximum elevation of $826 \mathrm{~m}$, mean temperature of $12{ }^{\circ} \mathrm{C}$ and annual rainfall of 2,293 $\mathrm{mm}$ (DGA 2004). In the watershed, the grassland, native forest habitat, exotic species forest plantations, shrubland and other uses (wetlands, bare soil, urban area and bodies of water) account for $31 \%$, $29 \%, 21 \%, 16 \%$ and $3 \%$ of the total area of landscape, respectively. The watershed has a human population of approximately 206,000 , which is equivalent to a population density of 46 people $\mathrm{km}^{-2}$ (DGA 2004). The main economic activities in the watershed are forestry, agriculture and livestock farming (DGA 2004).

Each of the 262 subwatersheds, ranging $500-4,000$ ha in size, was defined as the spatial unit of analysis. The delimitation of the subwatersheds and all spatial analyses in the study was carried out using the ArcGIS 9.3 (ESRI 2009).

Analysis of biodiversity. We analyzed the diversity of native forest habitats as a proxy for biodiversity at the landscape level. This diversity was determined by the variety and abundance of native forest habitats. The different types of habitats were determined by the presence of native forest in different vegetation levels, climatic zones and soil orders present in the study area. Vegetation levels are areas characterized by plant communities that have specific physiognomy and species dominance (Luebert and Pliscoff 2004). Climatic zones determine the presence of plant species in the landscape. These zones are defined by variables such as precipitation, moisture and temperature (Schlatter

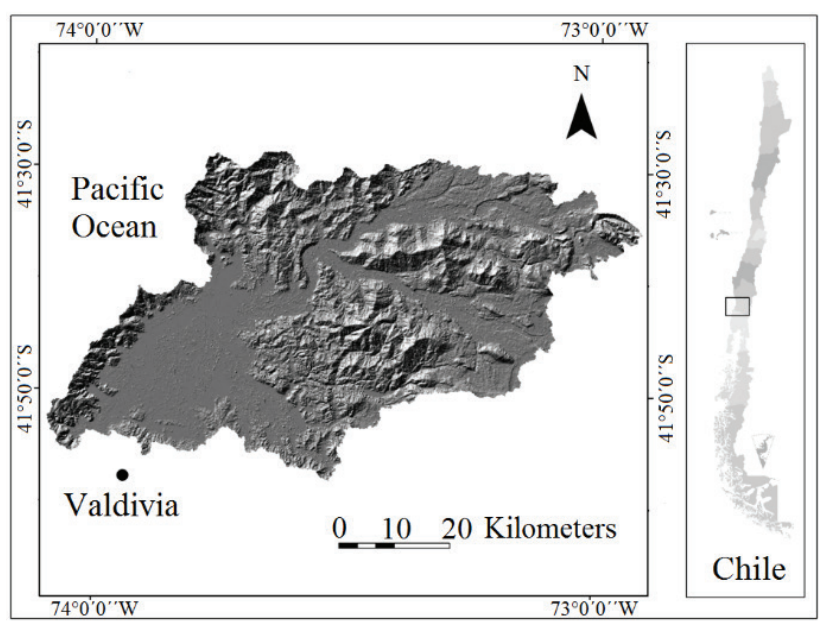

Figure 1. Location of the Rio Cruces watershed, Chile. Ubicación de la Cuenca del río Cruces, Chile. et al. 1995). Soil orders determine the establishment and development of the types of plant species, due to physicalchemical properties and morphological characteristics of the soil (CIREN 2003). Native forest habitats mapping was carried out using the following maps: 1) Map of native forest, which was extracted from land-use maps, was derived from Landsat satellite image (TM) for the year 2011 (Heilmayr et al. 2016). In this map, the following categories of land-use were identified: native forest, exotic species forest plantations, shrubland, grassland, wetland and other uses (bare soil, urban area and water bodies); 2) Map of vegetation levels by Estudio de Clasificación de Pisos de Vegetación (Study of Flats Vegetation Classification) (Luebert and Pliscoff 2004). In this map, ten vegetation levels were identified (table 1);3) Map of climatic zones provided by Sistema de Ordenamiento de la Tierra (Ordering System from the Earth) (Schlatter et al. 1995); 4) Map of soil orders provided by Estudio Agrológico de Suelos de Chile (Chile Agrological soil study) (CIREN 2003). The map of native forest habitats was derived from the calculation from the overlap of these maps. Diversity of the native forest habitats were assessed through Shannon diversity index, which is a landscape metric that relates the variety and abundance of different habitat types. The Shannon diversity index was used as a measure of relative amount of each habitat type in each unit of analysis. The index is expressed by the following formula [1] (Mcgarigal et al. 2002):

$$
H=-\sum_{i=1}^{s}(p i \times \ln P i)
$$

Where: $\mathrm{P}_{\mathrm{i}}=$ proportion of landscape occupied by habitat type "i".

The analysis of Shannon diversity index was carried out using FRAGSTATS (Mcgarigal et al. 2002). The map of native forest habitats was entered into FRAGSTATS and values of the Shannon diversity index were obtained for each subwatershed. All maps used in the study (input and output) had a spatial resolution of $30 \times 30$ m pixels, which is a resolution appropriate for the spatial analysis (Mcgarigal et al. 2002).

$\mathrm{N}$-Spect model and ecosystem services. The N-Spect software (No Point Source Pollution and Erosion Comparison Tools) was used to map and analyze the provision of the ecosystem services water supply and erosion control. NSpect software was developed to analyze and predict soil erosion through the amount of sediments exported and the potential impacts on water quality from nonpoint sources of pollution (NOAA 2009). N-Spect is a spatially explicit model that uses spatial elevation data to calculate flow direction and flow accumulation throughout a watershed. This software uses data on land cover, types of soils and 
precipitation to estimate runoff volume obtained after the filtering and retention water. N-Spect also uses the Revised Universal Soil Loss Equation to calculate erosion. The outputs of this software are maps that register the estimates of cumulative runoff and amount of sediment (NOAA 2009).

The parameterization of N-Spect was carried out taking into account the following inputs: 1) Digital elevation model (DEMs) $30 \times 30 \mathrm{~m}$, which was obtained from the Shuttle Radar Topography Mission (SRTM); 2) Map of land-use, in which the following land-use categories were identified: native forest, exotic species forest plantations, shrubland, grassland, wetland and other uses (bare soil, urban area and water bodies); 3) Maps of annual precipitation and rainfall erosivity ( $\mathrm{R}$ factor), which combine the effect of duration, magnitude and intensity of each rainfall event. The average annual rainfall erosivity was calculated from daily rainfall data registered in 18 meteorological stations located in the study area, using the method and formula [2] proposed by Angulo-Martínez and Beguería (2009):

$$
E I=E I_{30}=\left(\sum_{r=1}^{0} e_{r} v_{r}\right) I_{30}
$$

Where: $e_{\mathrm{r}}$ and $v_{\mathrm{r}}$ are, respectively, the unit rainfall energy $\left(\mathrm{MJ} \mathrm{ha}^{-1} \mathrm{~mm}^{-1}\right.$ ) and the rainfall volume $(\mathrm{mm})$ during a time period $\mathrm{r}$, and $\mathrm{I}_{30}$ is the maximum rainfall intensity in a 30 min period during the event $\left(\mathrm{mm} \mathrm{h}^{-1}\right)$.

The unit rainfall energy $\left(e_{\mathrm{r}}\right)$ is calculated for each time interval by the following formula [3] Angulo-Martínez and Beguería (2009):

$$
e_{r}=0.29\left[1-0.72^{-0.05 i_{r}}\right]
$$

Where: $i_{\mathrm{r}}=$ rainfall intensity during the time interval $\left(\mathrm{mm} \mathrm{h}^{-1}\right)$.

These annual averages were spatialized using geostatistical method of topoclimatological interpolation (Angulo-Martínez and Beguería 2009); 4) Values of vegetation cover ( $\mathrm{C}$ factor), which reflects the effect of different crops and management practices on erosion rates. These values were estimated on the basis of map of land-use and values proposed by Wischmeier and Smith (1978); 5) Coefficient of soil erodibility ( $\mathrm{K}$ factor), which depend on the texture, structure and content of organic matter presented by the soil series. These coefficients were calculated using information from CIREN (2003), using the equation of the nomogram proposed by Wischmeier and Smith (1978); 6) Values for hydrological groups for each soil series; these values are related to the number curve method that is based on the permeability of different soil series (NOAA 2009). The values from the hydrological groups were estimated from soil texture data (CIREN 2003). Information on the different soil series that form part of the study area was entered into a map, which was provided in CIREN (2003).
Model validation was carried out with the data registered in four precipitation and sediment stations of the General Directorate of Water present in the study area. The goodness of model fit was assessed by the method of quantitative assessment of "relative efficiency" proposed by Thanapakpawin et al. (2007). The relative efficiency is expressed by the following formula [4]:

$$
E_{r e l}=1-\frac{\sum_{i=1}^{N}\left(\frac{C i-\dot{C} l}{C i}\right)^{2}}{\sum_{i=1}^{N}\left(\frac{C i-\bar{C}}{C}\right)^{2}}
$$

Where: $C_{\mathrm{i}}=$ observed discharge, $C^{\prime}{ }_{\mathrm{i}}=$ simulated discharge, $\hat{\mathrm{C}}=$ mean observed discharge, and $\mathrm{N}=$ total number of samples.

Erel measures the goodness of model fit by comparing the volume of the discharge. The difference between simulated and observed values was quantified using relative deviations instead of absolute values (Thanapakpawin et al. 2007).

Water supply. This ecosystem service is the volume of water produced $\left(\mathrm{m}^{3} \mathrm{ha}^{-1}\right)$ per subwatershed (de Groot et al. 2010). This service is the water potentially available to humans (Chan et al. 2006). Water supply refers to the runoff volume obtained after filtering and retention water (de Groot et al. 2010). Filtering is mainly performed by the vegetation cover and soil. Retention capacity depends on topography and subsurface characteristics of the landscape. This ecosystem service was modeled by N-Spect using precipitation, land cover, soil and digital elevation model as parameters.

Erosion control. This ecosystem service is the ability of natural vegetation to curb erosion by holding onto soil (Egoh et al. 2009), which is measured as the amount $\left(\mathrm{Mg} \mathrm{ha}^{-1}\right)$ of sediment exported from each subwatershed (de Groot et al. 2010). Soil erosion removes nutrients and reduces fertility (de Groot et al. 2010), and may generate sedimentation and eutrophication of nearby rivers (Egoh et al. 2009). Therefore, areas where vegetation holds the soil need to be managed to allow continuous delivery of multiple services (de Groot et al. 2010). In this study erosion control services were modeled using the amount of sediment exported. These ecosystem services were modeled by N-Spect using the Revised Universal Soil Loss Equation.

Soil accumulation. This ecosystem service is directly linked to the accumulation of organic matter in the soil (Egoh et al. 2009). Experts in this area have registered a positive correlation between soil depth and vegetation coverage with the organic matter present in the soil (Egoh et al. 2009). Accordingly, these two variables have been used for modeling soil formation. In this study, the soil depth 
and coverage of different native forest habitats were used as proxies for soil accumulation. Values of depth of the soil series were obtained from CIREN (2003). The thresholds of depth $\leq 1 \mathrm{~m}$ (slightly depth) and $>1 \mathrm{~m}$ (depth) were used in the modeling; these thresholds were based on literature (CIREN 2003). The values of coverage of different native forest habitats were obtained from the map of native forest habitats. This ecosystem service was modeled using the index of soil accumulation (Egoh et al. 2009). This index was calculated for each subwatershed from the weighting of the areas of vegetation coverage in the areas of the different soil series that registered different thresholds of depth. Subsequently, the weighted areas were summed and the value obtained was divided into the total area of the subwatershed. The index of soil accumulation was spatialized for each subwatershed through the ArcGIS.

Ecosystem services hotspots. The term ecosystem service hotspot refers to areas that provide large proportions of a particular service, and do not consider measures of threat or endemism (Egoh et al. 2009, Bai et al. 2011, Onaindia et al. 2013). The hotspot mapping for each ecosystem service was carried out using the maps of continuous variables obtained in the modeling. Each map was divided into five classes, with the highest value considered as the ecosystem service hotspot. The classes were determined in each map using the Jenks Natural Breaks classification in ArcGIS (Onaindia et al. 2013). Natural Breaks classes are based on natural groupings inherent in the data. Class Breaks identifies the best group of similar values and maximizes the differences among classes (Onaindia et al. 2013).

Evaluating spatial congruence. Geographically weighted regression and the overlap analysis were used in our research to evaluate the relationship and spatial congruence between biodiversity and provision of ecosystem services.

Geographically weighted regression model. The geographically weighted regression is an extension of the traditional standard regression framework by allowing local, rather than global parameters, to be estimated (Fotheringham et al. 2002). It is a type of local statistics that can produce a set of local parameter estimates that show how relationships vary in space, and allows examination of the spatial pattern of the local estimates for better understanding of hidden possible causes of this pattern (Fotheringham et al. 2002). In contrast, the traditional regression method, such as Ordinary Least Squares, is a type of global statistics that assumes the relationship under study is constant over space. The geographically weighted regression model can be expressed by the following formula [5]:

$$
y_{i}=\beta_{0}\left(u_{j}, v_{j}\right)+\sum_{1=1}^{p} \beta_{i}\left(u_{j}, v_{j}\right) X_{i j}+\varepsilon_{j}
$$

Where: $u_{j}$ and $v_{j}$ are the coordinates for each location $j, \beta_{0}$ $\left(u_{j}, v_{j}\right)$ is the intercept for location $j, \beta_{i}\left(u_{j}, v_{j}\right)$ is the local parameter estimate for independent variable $x_{i}$ at location $j$.

The geographically weighted regression is calibrated by weighting all observations (values of biodiversity and ecosystem services) around a sample point or zone centroid using a distance decay function, assuming the observations closer to the location of the sample point have higher impact on the local parameter estimates for the location. The weighting function can be stated using the following formula [6]:

$$
W_{i j}=\exp \left(\frac{-d i j^{2}}{b^{2}}\right)
$$

Where: $w_{i j}=$ weight of observation $j$ for observation $i, d_{i j}$ $=$ distance between observation $\mathrm{i}$ and $\mathrm{j}, \mathrm{b}=$ kernel bandwidth.

When the distance is larger than the kernel bandwidth, the weight rapidly approaches zero. Both, fixed and adaptive kernel bandwidth, can be chosen for geographically weighted regression. Fixed kernel has a constant bandwidth over space, while adaptive kernel can adapt bandwidths in size to variations in data density so that bandwidths are larger in the locations where data are sparse, and smaller where data are denser. We used adaptive kernel bandwidth in this study, as the sample density varies over the study area. The optimal bandwidth was determined by minimizing the corrected Akaike Information Criterion (Fotheringham et al. 2002).

In order to compare the ability to deal with spatial autocorrelation of geographically weighted regression models, global Moran's I was calculated for the residuals. Moran's I is a commonly used indicator of spatial autocorrelation. The value of Moran's I ranges from -1 to 1 . A value of 1 means perfect positive spatial autocorrelation, a value of -1 suggests perfect negative spatial autocorrelation, and a value of 0 indicates perfect spatial randomness (Fotheringham et al. 2002). If significant spatial autocorrelation exists in the model, then this violates the assumption of randomly distributed and independent residuals in regression models. The efficiency of the model is therefore suspect. In addition, the residuals may contain some geographic information that the model does not include (Fotheringham et al. 2002).

The spatially varying relationships between biodiversity and provision of ecosystem services were analyzed in all spatial units of analysis using geographically weighted regression. The provision of ecosystem services was used as dependent variables, while biodiversity was the independent variable. All the geographically weighted regression analyses, Moran's I values and mappings were conducted using ArcGIS 9.3 (ESRI 2009). 
Overlap analysis. Spatial overlap expresses the area shared between two services as a percentage of the area of the service with a smaller total area (Egoh et al. 2009). Proportional overlap was used to measure overlap between ecosystem services hotspots and biodiversity. The area of each ecosystem service hotspot and biodiversity was measured using respective maps. The map of each ecosystem service hotspot and biodiversity was overlaid using geographic information system. The area of ecosystem service hotspot that overlapped with biodiversity was estimated and expressed as a percentage of total area of hotspot.

\section{RESULTS}

Model accuracy. The modeling of the ecosystem services carried out in the N-Spect software registered high accuracy. The modeling of the service water supply registered an efficiency of 0.93 , and that of the service erosion control registered an efficiency of 0.95 . These results are a reliable representation of hydrologic processes and sediment loads. The models accuracy reveals that $\mathrm{N}$-Spect is a versatile software that integrates multiple environmental variables that can support the effective watershed management.

Biodiversity. In the landscape studied, ten types of native forest habitats were recorded (table 1 and figure 2). These were determined by the presence of the Valdivian Temperate Forest in ten vegetation levels, two climatic zones and two soil orders (table 1). The ten types of native forest habitats had an area that ranged from 83 to 9,624 ha (table 1 and figure 2). In the 262 subwatersheds, which represent the spatial units of analysis, the Shannon diversity index ranged from 0.4 to 1.7 .

Spatial distribution. Biodiversity and ecosystem service hotspot showed important differences in spatial distribution. Biodiversity registered $85 \%$ of their distribution in Cordillera (figure 3). The hotspots of water supply and soil accumulation services reported $97 \%$ and $95 \%$ of their distribution in Cordillera, respectively (figure 3 ). In contrast, the hotspot of erosion control service registered $72 \%$ of their distribution in the flat areas of the watershed.

Spatial relationships. The set of local regression results showed important differences in the spatial relationships between biodiversity and provision of ecosystem service (figure 4). The local parameters estimates are positive for provision of the three ecosystem services in some subwatersheds and negative in other subwatersheds (figure 4). The positive relationships between biodiversity and water supply, erosion control and soil accumulation were registered in $97 \%, 85 \%$ and $74 \%$ of the subwatersheds studied, respectively (figure 4).

Regarding local $\mathrm{R}^{2}$ value, biodiversity can explain up to $95 \%, 68 \%$ and $37 \%$ of the variance in the provision of soil accumulation, water supply and erosion control, respectively; and $23 \%, 15 \%$ and $12 \%$ of the subwatersheds studied (figure 4). Standardized residuals for the three models ranged from -1.60 to 3.4 (figure 4 ). The results of Moran's I statistics were $0,-0.08$ and $-0.06(P<0.05)$ for water supply, erosion control and soil accumulation, respectively. These results show there is no significant spatial autocorrelations in the residuals. Therefore, the geographically weighted regression model is efficient.

The study landscape registered important differences in the size of the ecosystem service hotspot (table 2). The hotspot of erosion control and soil accumulation services reported the largest areas in the landscape, $58 \%$ and $36 \%$, respectively (table 2). Important spatial overlaps were registered in the landscape studied (table 2). Biodiversity registered high overlap with hotspots of water supply (77\%), erosion control (69 \%) and soil accumulation (67\%) (table 2). Among services, the highest overlap occurred between the hotspot of erosion control and soil accumulation (68\%) and erosion control and water supply (59\%) (table 2). The study landscape registered an important number of subwatersheds (nearly $50 \%$ ) with spatial overlaps between biodiversity and ecosystem services hotspots (figure 5).

\section{DISCUSSION}

$N$-Spect model accuracy. The high accuracy of the model (>0.93) shows that $\mathrm{N}$-Spect is a powerful tool for the spatial evaluation of the provision of ecosystem services. The N-Spect software model integrated a variety of information from the physical environment, and based on those data an innovative analysis on ecosystem services at landscape level was performed. This study demonstrates that $\mathrm{N}$-Spect has the potential to provide references to ecology planners and local stakeholders to address landscapes issues at different spatial scales. Since the validation of $\mathrm{N}$-Spect models was carried out with data recorded in the four precipitation and sediment stations present in the study area, the validation may have a little inaccuracy. Therefore, it is necessary that future studies use a larger number of stations to obtain superior accuracy in the modeling.

Geographically weighted regression models. The geographically weighted regression technique provides a simple, though powerful, tool to explore the spatial variation of the relationship among biodiversity and water supply, erosion control and soil accumulation. The benefits obtained from using the geographically weighted regression are to help to identify the spatial patterns of the spatial relationship and to prioritize conservation areas. This study has demonstrated that the geographically weighted regression has the potential to provide references to ecological planners and local stakeholders to address landscapes issues at different spatial scales.

Spatial congruence. Our results indicate that biodiversity co-occurs with the ecosystem services, which suggests 
Table 1. Types of native forest habitat and their area in the Río Cruces watershed.

Tipos de hábitat de bosque nativo y sus áreas en la Cuenca del río Cruces, Chile.

\begin{tabular}{|c|c|c|c|c|c|}
\hline \multirow{2}{*}{ Habitat type } & \multicolumn{4}{|c|}{ Variables } & \multirow{2}{*}{$\begin{array}{c}\text { Area of the } \\
\text { habitat type } \\
\text { (ha) }\end{array}$} \\
\hline & $\begin{array}{l}\text { Native } \\
\text { forest }\end{array}$ & Vegetation levels & Climatic zone & Soil orders & \\
\hline I & VTF & $\begin{array}{l}\text { Andean temperate deciduous forest of Nothofagus } \\
\text { alpina and Dasyphyllum diacanthoides }\end{array}$ & Zone 2 , district 0 & Andisol & 2,013 \\
\hline II & VTF & $\begin{array}{l}\text { Andean temperate deciduous forest of Nothofagus } \\
\text { alpina and Nothofagus dombeyi }\end{array}$ & Zone 2 , district 0 & Andisol & 836 \\
\hline III & VTF & $\begin{array}{l}\text { Temperate deciduous forest of Nothofagus obliqua } \\
\text { and Laurelia sempervirens }\end{array}$ & Zone 1 , district 0 & Andisol & 771 \\
\hline IV & VTF & $\begin{array}{l}\text { Temperate deciduous forest of Nothofagus obliqua } \\
\text { and Laurelia sempervirens }\end{array}$ & Zone 1 , district 0 & Ultisol & 4,714 \\
\hline $\mathrm{V}$ & VTF & $\begin{array}{l}\text { Temperate deciduous forest of Nothofagus obliqua } \\
\text { and Laurelia sempervirens }\end{array}$ & Zone 2 , district 0 & Andisol & 7,990 \\
\hline VI & VTF & $\begin{array}{l}\text { Temperate deciduous forest of Nothofagus obliqua } \\
\text { and Laurelia sempervirens }\end{array}$ & Zone 2 , district 0 & Ultisol & 9,624 \\
\hline VII & VTF & $\begin{array}{l}\text { Temperate laurifolio forest of Nothofagus dombeyi } \\
\text { and Eucryphia cordifolia }\end{array}$ & Zone 1 , district 0 & Andisol & 83 \\
\hline VIII & VTF & $\begin{array}{l}\text { Temperate laurifolio forest of Nothofagus dombeyi } \\
\text { and Eucryphia cordifolia }\end{array}$ & Zone 1 , district 0 & Ultisol & 1,227 \\
\hline IX & VTF & $\begin{array}{l}\text { Temperate laurifolio forest of Nothofagus dombeyi } \\
\text { and Eucryphia cordifolia }\end{array}$ & Zone 2 , district 0 & Andisol & 1,319 \\
\hline$X$ & VTF & $\begin{array}{l}\text { Temperate laurifolio forest of Nothofagus dombeyi } \\
\text { and Eucryphia cordifolia }\end{array}$ & Zone 2 , district 0 & Ultisol & 4,507 \\
\hline
\end{tabular}

Characteristics of climatic zones (Schlatter et al. 1995) and soil orders:

- Climatic zone 1, district 0: Total annual precipitation (mm): 1,900 min - 2,000 max. Annual moisture index 2.0 min. - 2.5 max. Dry period 1 - 2 months/year. Frost-free period $200-250$ days/year. Total number of frost $10-20$ days/year. Estival moisture index 0.5 min -0.6 max. Average relative humidity in January $70 \%-80 \%$. Annual absolute temperature min $-6{ }^{\circ} \mathrm{C}$, frequency of occurrence $1 \mathrm{month} /$ year.

- Climatic zone 2, district 0: Total annual precipitation (mm): 1,900 min - 3,000 max. Annual moisture index 2.0 min. - 2.5 max. Dry period $1-2$ months/year. Frost-free period 120 - 200 days/year. Total number of frost 20 - 30 days/year. Estival moisture index 0.5 min - 0.6 max. Average relative humidity in January $65 \%-70 \%$. Annual absolute temperature $-6{ }^{\circ} \mathrm{C}$, frequency of occurrence $2 \mathrm{month} / \mathrm{year}$.

- Andisol order: Soil derived from volcanic ash. These soils in Chile correspond to Trumaos and Nadis soils. Andisol soils have excellent physical and morphological conditions, whereby can be grown easily. These soils have large amounts of phosphorus, though it is retained in the soil in a form that is not available to plants. Therefore, these soils require large amounts of phosphatic fertilizations to obtain high yields.

- Ultisol order: Soils with B Horizon well expressed due to an increase of clay in the A horizon. These soils are highly leached. Consequently, it has low levels of nutrients. These soils require large amounts of fertilization to obtain reasonable yields.

+ Valdivian Temperate Forest

Table 2. Extent and proportional overlap between biodiversity and ecosystem services hotspots in the Río Cruces watershed.

Extensión y superposición proporcional entre biodiversidad y hotspots de servicios ecosistémicos en la Cuenca del río Cruces, Chile.

\begin{tabular}{lccccc}
\hline & \multicolumn{2}{c}{ Proportional overlap } & Area \\
\cline { 2 - 5 } & Biodiversity & Water supply & $\begin{array}{c}\text { Erosion } \\
\text { control }\end{array}$ & $\begin{array}{c}\text { Soil } \\
\text { accumulation }\end{array}$ & $\begin{array}{c}\text { \% of study area covered by the } \\
\text { ecosystem service hotspot }\end{array}$ \\
\hline Biodiversity & 100 & & & 55 & 20.3 \\
Water supply & 77 & 100 & 100 & 58 & 36 \\
Erosion control & 69 & 59 & 68 & 100 & 58 \\
Soil accumulation & 67 & 53 & & & \\
\hline
\end{tabular}




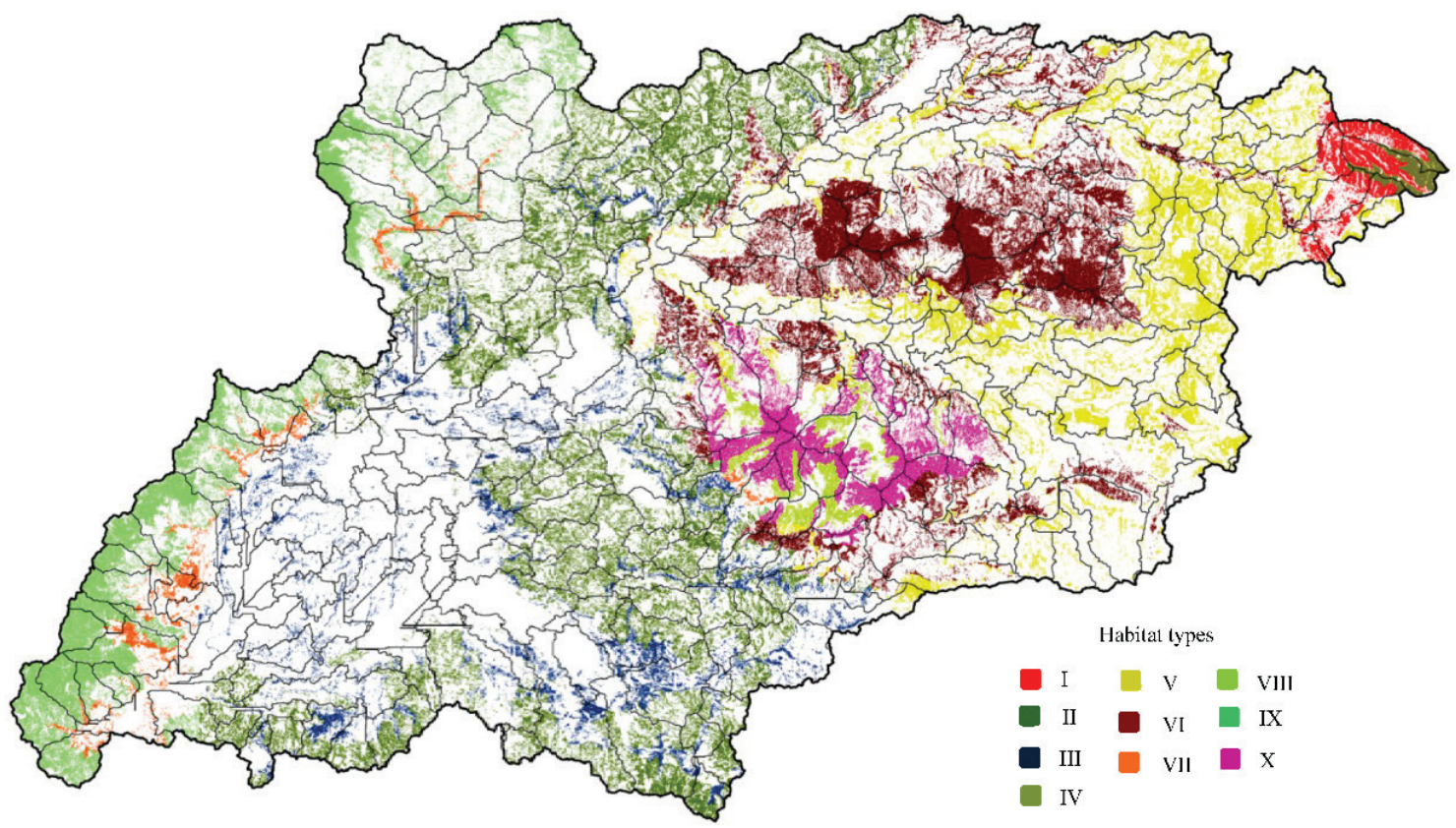

Figure 2. Spatial distribution of native forest habitat types in the Rio Cruces watershed, Chile. Table 1 shows features of each habitat type. Distribución especial de los tipos de hábitat de bosque nativo en la Cuenca del río Cruces, Chile. En el cuadro 1 se presentan las características de cada tipo de hábitat.
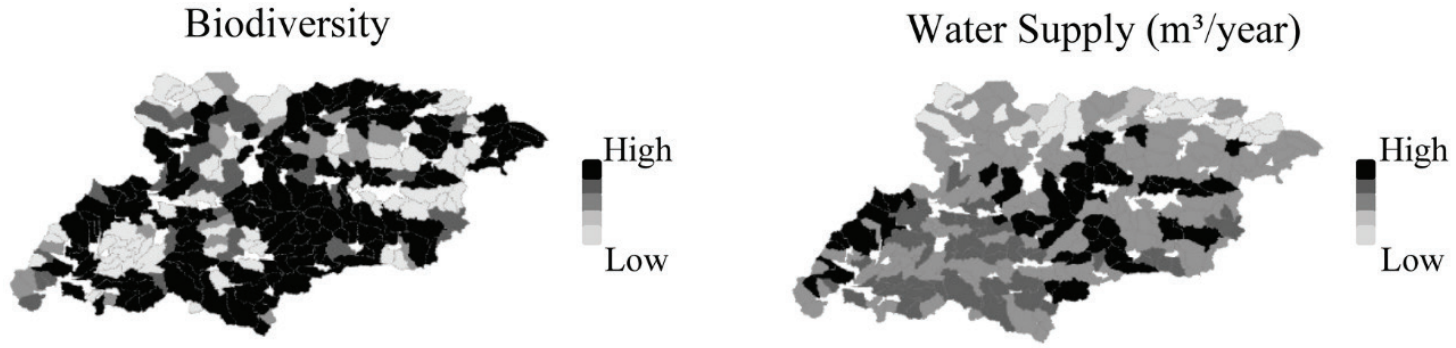

\section{Erosion Control}

(Sediment export $\mathrm{Mg} \mathrm{ha}^{-1}$ year $^{-1}$ )

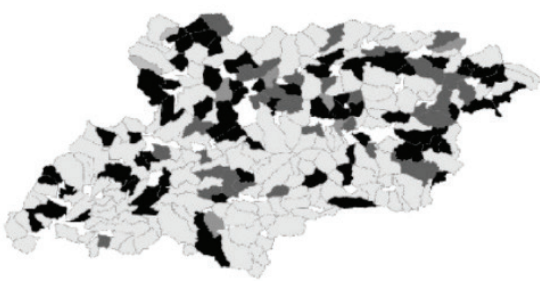

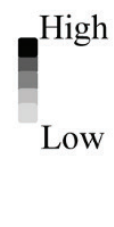

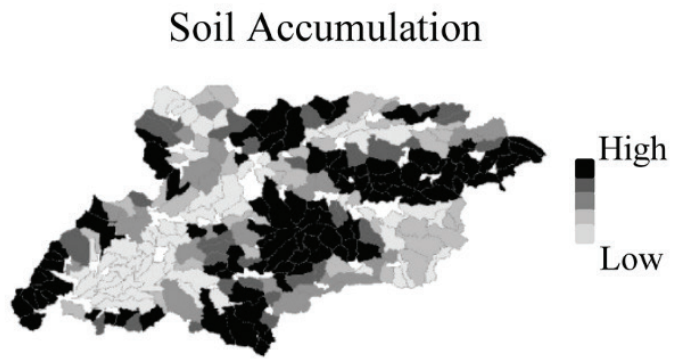

Figure 3. Spatial distribution of biodiversity and ecosystem services hotspots in the Rio Cruces watershed. The "high class" correspond to the hotspots.

Distribución especial de la biodiversidad y hotspots de servicios ecosistémicos en la Cuenca del río Cruces, Chile. La "clase alta" corresponde a los hotspots. 

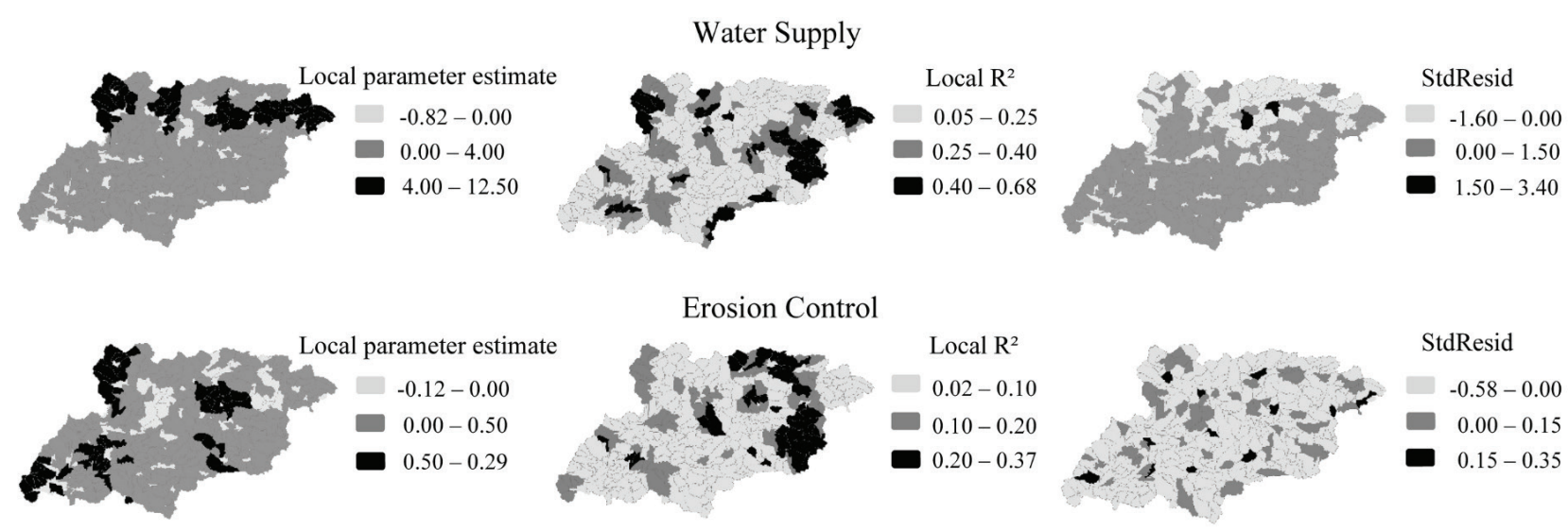

StdResid

Soil Accumulation
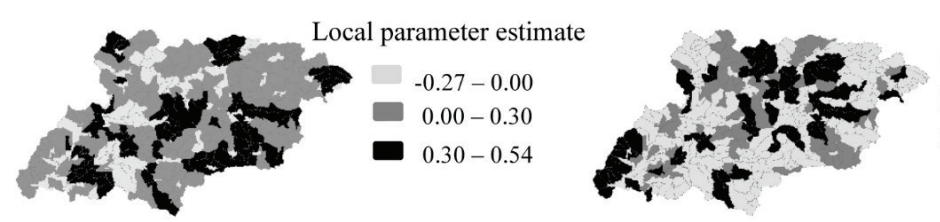

Local $\mathbf{R}^{2}$
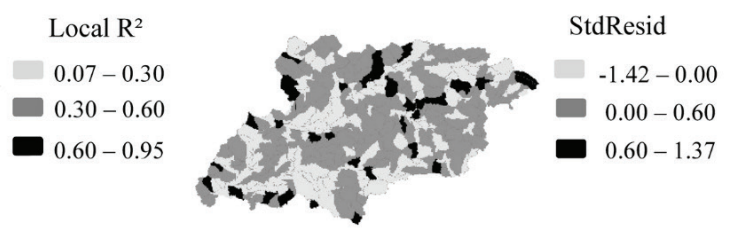

Figure 4. Spatial patterns of local $\mathrm{R}^{2}$, standardized residuals (StdResid) and local parameter estimates obtained from geographically weighted regression biodiversity models for water supply, erosion control and soil accumulation services.

Patrones espaciales de $\mathrm{R}^{2}$ local, residuos estandarizados y estimación de parámetros locales obtenidos desde modelos de regresiones geográficamente ponderadas entre biodiversidad y los servicios provisión de agua, control de erosión y acumulación de suelo.

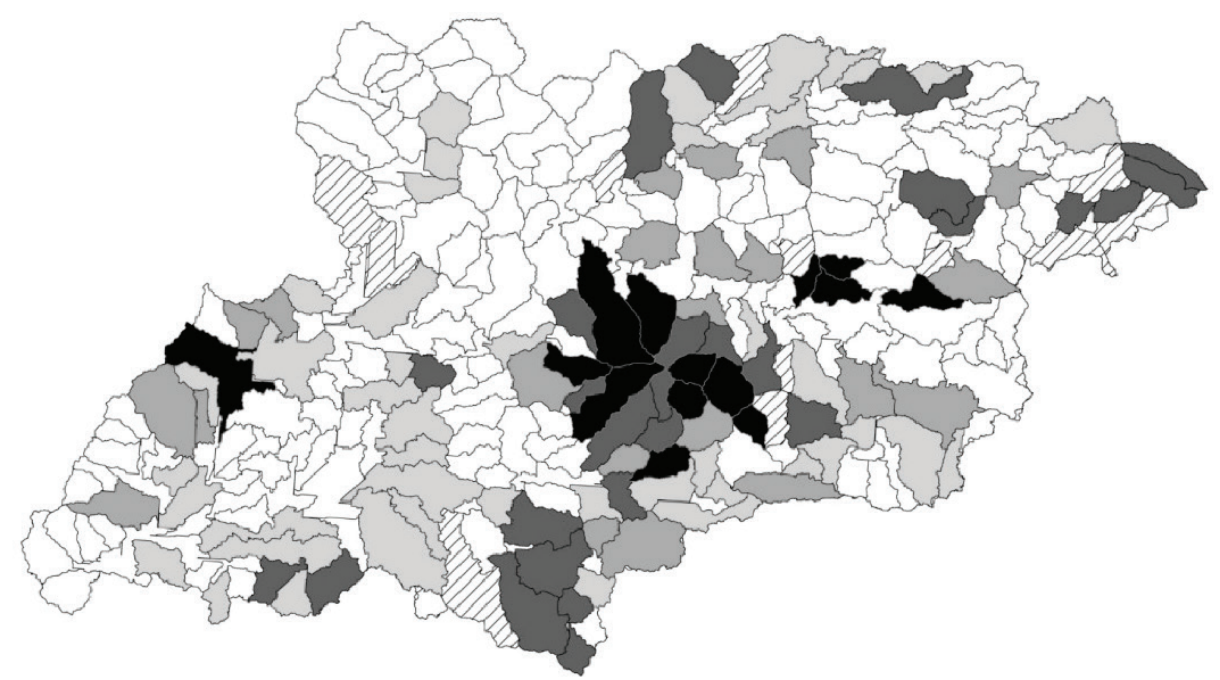

Biodiversity, water supply, erosion control and soil accumulation

Biodiversity and erosion control

Biodiversity, erosion control and soil accumulation

Biodiversity and soil accumulation

Biodiversity and water supply

Areas of ecosystem services provision which are not hotspot

Figure 5. Spatial congruence between biodiversity and ecosystem services hotspots in the Rio Cruces watershed, Chile.

Congruencia espacial entre biodiversidad y hotspots de servicios ecosistémicos en la Cuenca del río Cruces, Chile. 
that opportunities exist to use ecosystem services as an additional rationale for biodiversity conservation. These opportunities exist mostly in the Cordillera areas where large distribution of the hotspots of soil accumulation and water supply services could be used to justify biodiversity conservation. Although the areas of ecosystem services hotspots are moderately small, there is a high percentage of these areas in Cordillera, which indicates the importance of the Cordillera areas in service delivery. The positive spatial relationship between biodiversity and ecosystem services may justify opportunities for the biodiversity conservation in an effort to protect the provision of services (Turner et al. 2007). In addition, our result shows that the positive spatial relationship between biodiversity and the three ecosystem services (nearly $97 \%$ of the subwatersheds studied) justifies the use of these two services in biodiversity conservation. Conversely, the subwatersheds with a negative spatial relationship identify a conflict area that does not provide an ecosystem service as an additional rationale for biodiversity conservation. Therefore, we suggest that the conservation in these areas should be focused on a single goal.

Our study shows that the relationships between biodiversity and ecosystem services vary spatially due to availability of these resources in the landscape. This availability is determined by the abundance and variety of the native forest habitats and different abiotic factors, such as soil, topography and regional climate. Thereby the availability and interaction among these variables determine the distribution and strength of the relationship between biodiversity and ecosystem services.

In addition, it is important to highlight that the spatial variation and availability of these resources can also depend of the land-use change and land-use intensification, which have increased in recent decades due to progressive pasture expansion for cattle grazing and commercial plantations (Echeverría et al. 2006). In this sense, we highlight the need to undertake multi-scale research, which allows understanding the influence of different abiotic factors and land-use change and land-use intensification on the strength of the relationship between biodiversity and ecosystem services.

Our findings show high synergies (nearly $70 \%$ ) among ecosystem services hotspots, which indicate that protecting these areas of multiple benefits would therefore be the most efficient conservation option. As such, the conservation of erosion control hotspots can protect $68 \%$ and 59 $\%$ of the provision of soil accumulation and water supply hotspots, respectively. Our results are similar to those registered in other threatened landscapes, such as in the Little Karoo region, a semiarid biodiversity hotspot in South Africa (Reyers et al. 2009) and the Baiyangdian watershed, China (Bai et al. 2011), where high synergies offer options to optimize the conservation. Finding areas of synergy may have some benefit, however the continuous provision of services will require appropriate targets for ecosystem services that will ensure the continuous provision. These targets should consider threats facing each service as is the case for biodiversity where critically endangered features are given priority.

Our results indicate high spatial congruence between biodiversity and ecosystem services hotspots. Spatial congruencies recorded in this study are similar to those registered in other biodiversity hotspots (Chan et al. 2006, Egoh et al. 2009). The congruence between biodiversity and ecosystem services differs among landscapes according to the spatial characteristics of each ecosystem (Turner et al. 2007). The landscape studied registered an important presence of biodiversity and provision of ecosystem services. Consequently, our study indicates that conservation of $68 \%$ of the area that registers highest biodiversity can protect the following ecosystem services hotspots: $77 \%$ of erosion control, $69 \%$ of water supply and $67 \%$ of soil accumulation (figure 5). However, our study highlights that there may be conflicts between the needs of biodiversity conservation and the management actions needed to maintain it in an area, and the management actions that would promote a given ecosystem services in the areas that show spatial congruence. Therefore, it is necessary to undertake detailed studies that allow identifying and understanding the compatibility between conservation efforts and management actions for biodiversity and ecosystem services in the study area.

The differences in the level of congruence between ecosystem services hotspots and biodiversity indicate that the services are driven by different variables; each should be considered separately in conservation assessments. Our results also suggest that no single biodiversity level can be used to evaluate the spatial relationship with ecosystem services. Congruencies between biodiversity and services may vary from service to service depending on the biodiversity data used and the scale of study. Therefore, our results should be interpreted with caution until congruence is examined within an exhaustive list of ecosystem services and biodiversity at different levels.

Our findings indicate that 43 subwatersheds (nearly $20 \%$ of the subwatersheds studied) exhibit the most important strength in the positive relationship between biodiversity and ecosystem services and spatial congruence between these resources (figure 6). Therefore, these subwatersheds are the areas of the landscape in which it is recommended to perform simultaneous conservation efforts. Previously, the management of most existing conservation areas in the landscape studied was mainly concerned with biodiversity (Myers et al. 2000, CONAF 2006) and largely ignored the protection of ecosystem services. Our results provide key knowledge that can be used to perform simultaneous conservation strategies and to assist in practical decision making.

\section{CONCLUSIONS}

Our study constitutes the most extensive analysis of spatial relationship between biodiversity and ecosystem 


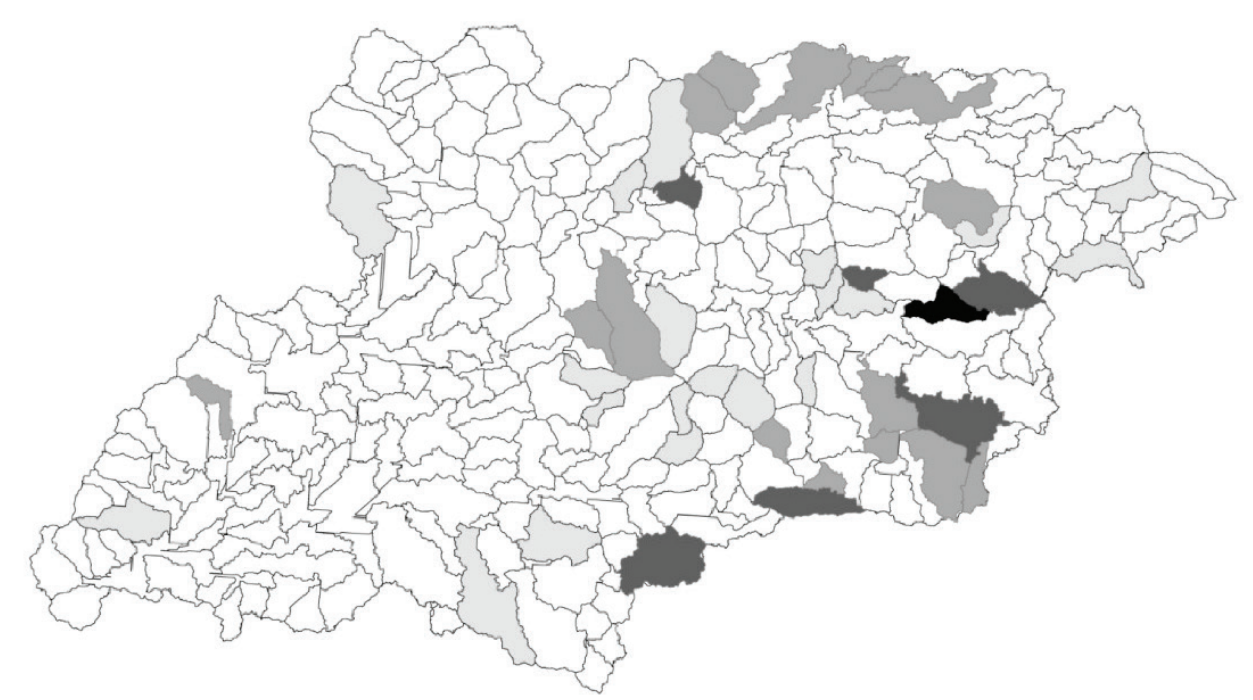 Biodiversity,
accumulation
$\square$ Biodiversity and water supply
$\square$ Biodiversity and erosion control

Biodiversity and soil accumulation

Areas of biodiversity and/or provision of ecosystem services

Figure 6. Priority conservation subwatersheds according to the greater strength in the positive relationship between biodiversity and ecosystem services and spatial congruence between these resources in the Rio Cruces watershed, Chile.

Subcuencas con prioridad de conservación de acuerdo a la positiva relación entre biodiversidad y servicios ecosistémicos y las congruencias espaciales entre estos recursos en la Cuenca del río Cruces, Chile.

services conducted in Chile. The results demonstrate, at landscape scale, the different spatial relationships and identify the areas where simultaneous conservation of the biodiversity and ecosystem services can be realized. Our study highlights that the inclusion of ecosystem services in conservation planning has a great potential to provide opportunities for biodiversity protection. This research contributed to a better understanding of the spatial relationship between ecosystem services and biodiversity and the extent to which the conservation of biodiversity would ensure the provision of multiple services.

About suggestions for planning conservation, we recommend carrying out simultaneous conservation efforts in 43 subwatersheds (nearly $20 \%$ of the subwatersheds studied) that exhibit the superior strength in the positive relationship between biodiversity and ecosystem services and spatial congruence between these resources. These simultaneous conservation efforts will allow the optimization of conservation strategies and capital investment. Furthermore, we suggest that these conservation efforts be complemented with land-use planning and supported in a framework of environmental policies generated by the Chilean government. Currently, planning and management of biodiversity and ecosystem services are carried out by different organizations of the Chilean government. We want to emphasize that successful management of ecosystem services and biodiversity requi- res the engagement of multidisciplinary teams and related stakeholders.

\section{ACKNOWLEDGMENTS}

The authors are grateful to Dr. Jean Paul Metzger, Dr. Albert Hernández and Dr. Marco Nuti for their revision. Authors thank Laboratorio de Ecología de Paisaje (LEP) from Universidad de Concepción, Chile; and Laboratorio de Ecología de Paisaje y Conservación (LEPaC) from Universidad de Sao Paulo, Brasil. Special thanks also go to FONDECYT project 1140531 and MECESUP scholarship by Ministry of Education of Chile. We also greatly appreciate the valuable comments we received from anonymous reviewers.

\section{REFERENCES}

Angulo-Martínez M, S Beguería. 2009. Estimating rainfall erosivity from daily precipitation records: a comparison among methods using data from the Ebro Basin (NE Spain). Journal of Hydrology 379(1): 111-121.

Bai Y, C Zhuang, Z Ouyang, H Zheng, B Jiang. 2011. Spatial characteristics between biodiversity and ecosystem services in a human-dominated watershed. Ecological Complexity 8(2): 177-183.

Chan KMA, L Hoshizaki, B Klinkenberg. 2011. Ecosystem Services in Conservation Planning: Targeted Benefits vs. Co- 
Benefits or Costs? PLoS ONE 6: 1-14.

Chan KMA, MR Shaw, DR Cameron, EC Underwood, GC Daily. 2006. Conservation Planning for Ecosystem Services. PLoS Biology 4(11): e379.

CIREN (Centro de Información de Recursos Naturales, CL). 2003. Estudio Agroecológico: Descripciones de suelos materiales y símbolos. X Región. Santiago, Chile. CIREN. 374 p.

CONAF (Corporación Nacional Forestal, CL). 2006. Plan Integral de Gestión Ambiental del Humedal de Río Cruces. Valdivia, Chile. Corporación Nacional Forestal. 60 p.

de Groot RS, R Alkemade, L Braat, L Hein, L Willemen. 2010. Challenges in integrating the concept of ecosystem services and values in landscape planning, management and decision making. Ecological Complexity 7(3): 260-272.

DGA (Dirección General de Aguas, CL). 2004. Diagnóstico y clasificación de los cursos y cuerpos de agua según objetivos de calidad: Cuenca del río Valdivia. Valdivia, Chile. Ministerio de Obras Públicas, Gobierno de Chile. 123 p.

Di Marzio W, R McInnes. 2005. Misión Consultiva Ramsar: Chile (2005). Informe de Misión. Santuario Carlos Anwandter (Río Cruces). Valdivia, Chile. Misión Consultiva Ramsar. 56 p.

Díaz S, J Fargione, F Chapin, I Stuart, D Tilman. 2006. Biodiversity Loss Threatens Human Well-Being. PLoS Biology 4: e277.

Echeverría C, D Coomes, J Salas, J Rey-Benayas, A Lara, A Newton. 2006. Rapid deforestation and fragmentation of Chilean temperate forests. Biological Conservation 130: 481-494.

Egoh B, B Reyers, M Rouget, M Bode, DM Richardson. 2009. Spatial congruence between biodiversity and ecosystem services in South Africa. Biological Conservation 142: 553-562.

ESRI (Environmental Systems Research Institute, US). 2009. Environmental Systems Research Institute, Inc. In $380 \mathrm{New}$ York St., Redlands, CA92373-8100. USA. Consulted 21 Jun. 2015. Available in http://webhelp.esri.com/arcgisdesktop/9.3/index.cfm?TopicName=copyright\%20information

Fotheringham AS, C Brunsdon, ME Charlton. 2002. Geographically weighted regression: The analysis of spatially varying relationships. New York, USA. Wiley. 284 p.

Heilmayr R, C Echeverría, R Fuentes, E Lambin. 2016. A plantation-dominated forest transition in Chile. Applied Geography 75: 71-82.

Luebert F, P Pliscoff. 2004. Clasificación de pisos de vegetación y análisis de la representatividad ecológica de áreas propuestas para la protección de la ecorregión valdiviana. Valdivia, Chile. Serie de Publicaciones WWF Chile. Programa Ecorregión Valdiviana. 174 p.

Mcgarigal K, SA Cushman, MC Neel, E Ene. 2002. Fragstats: Spatial Pattern Analysis Program for Categorical Maps.
Computer software program produced by the authors at the University of Massachusetts, Amherst. Consulted 15 ene. 2015. Available in http://www.umass.edu/landeco/research/ fragstats/fragstats.html.

MA (Millennium Ecosystem Assessment, US). 2005. Ecosystems and Human Well-Being: Synthesis. Washington, DC: Island Press. $141 \mathrm{p}$.

Myers N, RA Mittermeier, CG Mittermeier, GAB da Fonseca, J Kent. 2000. Biodiversity hotspots for conservation priorities. Nature 403: 853-858.

NOAA (National Oceanic and Atmospheric Administration, US). 2009. Tutorial for the Nonpoint-Source Pollution and Erosion Comparison Tool (N-SPECT). Extension for ESRI, ArcGIS. USA: NOAA Coastal Services Center. 42 p.

Onaindia M, B Fernández de Manuel, I Madariaga, G RodríguezLoinaz. 2013. Co-benefits and trade-offs between biodiversity, carbon storage and water flow regulation. Forest Ecology and Management 289(1): 1-9.

Oyarzún CE, C Frêne, G Lacrampe, A Huber, P Hervé. 2011. Propiedades hidrológicas del suelo y exportación de sedimentos en dos microcuencas de la Cordillera de la Costa en el sur de Chile con diferente cobertura vegetal. Bosque 32(1): 10-19.

Reyers B, PJ O'Farrell, RM Cowling, BN Egoh, DC Le Maitre, JHJ Vlok. 2009. Ecosystem Services, Land-Cover Change, and Stakeholders: Finding a Sustainable Foothold for a Semiarid Biodiversity Hotspot. Ecology and Society 14(1): 38.

Rodríguez-Echeverry J, C Echeverría, L Nahuelhual. 2015. Impacts of anthropogenic land-use change on populations of the Endangered Patagonian cypress Fitzroya cupressoides in southern Chile: implications for its conservation. Oryx 49(3): 447-452.

Schlatter J, V Gerding, H Huber. 1995. Sistema de ordenamiento de la tierra. Herramienta para la planificación forestal aplicada a la X Región. Valdivia, Chile. Universidad Austral de Chile. 93 p.

Thanapakpawin P, J Richey, DThomas, S Rodda, B Campbell, M Logsdon. 2007. Effects of landuse change on the hydrologic regime of the Mae Chaem river basin, NW Thailand. Journal of Hydrology 334(1): 215-230.

Turner WR, K Brandon, TM Brooks, R Costanza, GAB da Fonseca, R Portela. 2007. Global Conservation of Biodiversity and Ecosystem Services. Bioscience 57(10): 868-873.

Vihervaara P, M Rönkä, M Walls. 2010. Trends in Ecosystem Service Research: Early Steps and Current Drivers. AMBIO 39(4): 314-24.

Wischmeier WH, DD Smith. 1978. Predicting Rainfall erosion losses: A Guide to conservation planning. Washington DC, United States. Science and Education Administration, Department of Agriculture. $60 \mathrm{p}$. 